\title{
The Role of Metacognition and Motivation in Developing the \\ Writing Skill: the Case of Second Year Students of English at University "des Frères Mentouri" Constantine 1
}

\begin{abstract}
:
Writing has an effective role in learning any language. It is a basic skill that endorses language acquisition, fosters critical thinking and permits students to communicate. Moreover, it becomes an essential competence for the learner to communicate in the globalized world and to achieve academicsuccess. This study is a fulfillment of the urgent need to make students aware of some metacognitive strategies that facilitate the writing task. It seeks to explore the efficiency of implementing metacognitive strategies via the use of the Process Approach in English Foreign Language writing classes to develop the students' written production. Two main tools are used which are the teachers and the students questionnaires, and a quasi- experimental research (pre test and post test). During the experimental study, the researcher used metacognitive strategies and taught the participants in the experimental group how to use them in their writing skill. Through this study, the researcher has attempted to create a motivating environment and aid the learners to write essays following the different recursive stages of the Process Approach as a metacognitive strategy. However, the participants in the control group did not receive any treatment during their writing practice. The results show that the written compositions of the experimental group are highly improved compared to the control group.

Keywords: Metacognition, motivation, strategies, the writing skill, the process approach.
\end{abstract}

\author{
Sahli Fatiha \\ Faculty of Letters and Languages \\ Department of Foreign Languages \\ University of Mentouri \\ Constantine
}

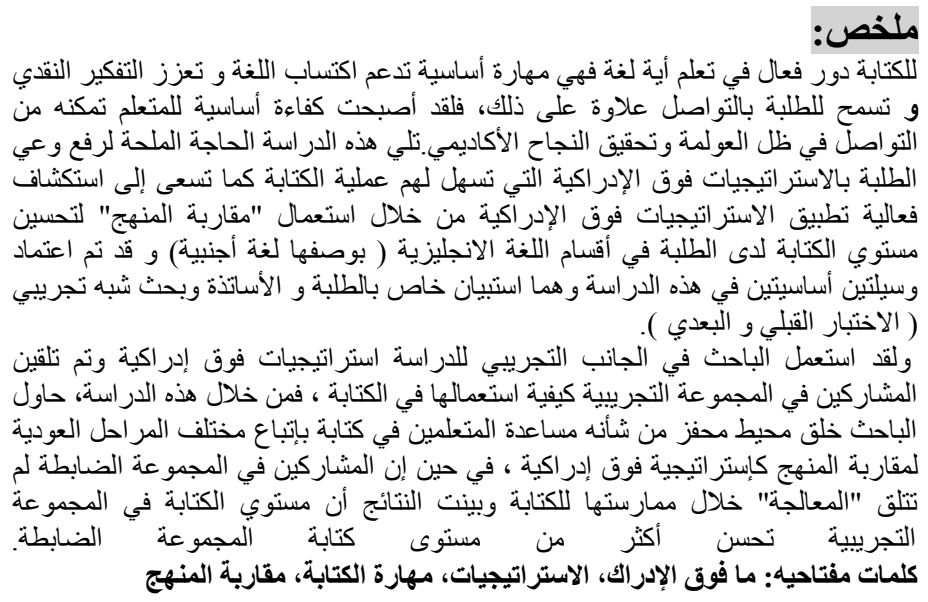

\section{Introduction :}

Writing is the way by which students express their ideas via a text. It is considered as the core of language process and constitutes a fundamental part of the curriculum in Higher Education. It is a lifelong skill: students are constantly asked to write in their studies not only in the Written Expression course but also in other courses. It is a basic skill that promotes language acquisition 
However, even at the level of the university, as teachers of Written Expression, we incessantly criticize the passive accumulation of knowledge and lack of awareness on the part of our students. We often observe that very few of our students develop their writing competence easily. The great majority deems this skill as the most difficult, the most challenging to be acquired and mastered; they are unmotivated; their passion for writing frequently seems to minimize, and they go through a slow and sterile process of writing. Teachers must actively involve their students in the writing process and serve as facilitator for them. Theyshould guide their learners through all the steps of their writing process by providing them with some metacognitive instructions. Our tenet aim of our study is to show the effectiveness of using instructions as metacognitive strategies to motivate students and promote their writing achievement. Indeed, when students are provided with some metacognitive instructions and guidance, and have an intrinsic motivation to write, they can persevere in developing their writing more and more to achieve a high level of competence. Both Metacognition and motivation contribute highly to develop students' writing achievement.

\section{The Writing Skill}

Writing has the most effective role in learning any language. It is a basic literacy skill which promotes language acquisition, fosters critical thinking and enables students to communicate. Moreover, it is an essential competence that learners must develop to enable them to communicate in the globalized world and to achieve academic success.

\subsection{Definition and Components of the Writing Skill}

Originally, Writing was defined as graphic symbols or visual marks. Brown (2001, p. 335) pointed out that "a simplistic view of writing would assume that written language is simply the graphic representation of spoken language". Later, a notion of coherence was added. Hyland (2003, p. 12) explained that writing is "marks on page or screen, a coherent arrangement of words, clauses, and sentences, structured according to a system of rules". These symbols must be arranged according to certain conventions and rules in order to form words, and then sentences to produce complete coherent text that communicates a message and expresses our thoughts and feelings.

Writing is not an easy task, and in order to be performed effectively and successfully, it requires some basic components. Raimes (1983,p. 6) categorized the components of writing, as content, the writer's process, 
audience, purpose, word choice, organization, mechanics, grammar and syntax. Most teachers agreed on the necessity of the writing components, although they realize that there are some aspects of writing students may find difficult. They consider the most important and challenging ones as content, organization, style, mechanics, and coherence

According to Scarry and Scarry (2014), when writing, learners have to include content or supporting details with regard to the method of development they use. Any piece of writing should be well-presented, well-structured, and well-organized. Organization is very essential; it helps the reader to follow the process of ideas easily and clearly. Starkey (2004, p. 2) highlighted the importance of organization, stating that "by following [an organized method of writing], you will guide your reader from your first to last sentence. He or she will be able to see how the various points you make in your [piece of writing] work together and how they support your thesis". Organization makes any production clear, understandable, and easy to follow. Frodesen and Holten (2003, p.141) argued that "for writing to be deemed successful to its overall purpose, it must conform to the conventions of English syntax and usage, generally referred to as grammar. Grammar is indisputably an essential element of second language writing instruction". Consequently, grammar is indeed an essential component of writing.

Style is defined as "the manner of writing that constitutes the collective characteristics of writing, impression or way of presenting things" (Madhuka, 2005, p.84). Stylistic writing is very imperative. While writing, the learner should select words that give more power, more quality to the text, attract the reader's attention and select the tone and structural relationships between words. The use of mechanics means the use of capitalization, punctuation, good spelling, and accurate grammar. The use of these elements helps the reader to comprehend the text, to follow the ideas smoothly and easily and adds to the piece of writing more significance and value. Angelillo (2002) considered that the most important element of mechanics is punctuation, "the system of little symbols [that] is full of meaning, nuance, and intricacy" (2002, p. 8). Coherence, on the other hand refers to the "clear connections between ideas, between sentences, and between paragraphs" (Carroll, 1990, p.7). It is a result of considering different factors, "which combine to make every paragraph; every sentence, and every phrase contribute to the 
meaning of the whole piece" (Kies, 1995). Murray and Hughes (2008, p. 45 ) noticed that a good writer is the one "who sticks his ideas together as links in a chain, each link connecting the one before it with the one after. If any links are missing, the connections become unclear and the argument's structure breaks down." To achieve coherence, writers use some important techniques, such as: repetition of key words, use of synonyms, pronouns to refer to key words, and careful choice of transitional expressions.

In addition to these components, a writer needs to acquire some competences. Canale and Swain's (1980) put forward a framework where they insisted that writers need at least four competencies: Grammatical Competence which refers to knowledge of grammar, vocabulary, and the language system; Discourse Competence referring to knowledge of genre and the rhetorical patterns that create them; Sociolinguistic Competence which is the ability to use language appropriately in different contexts, understanding readers and adopting appropriate authorial attitudes; and Strategic Competence, the ability to use a variety of communicative strategies.

\subsection{The Writing Approaches}

After several decades of researches in the field of second /foreign language writing several approaches have been developed. The main ones are the Controlled or Guided Composition, the Product Approach, the Process Approach, the Genre Approach and the Process Genre Approach.

The Controlled or Guided Composition was a manifestation of the popular structural-behaviorist percept from 1940's to 1960's. This approach stresses the importance of grammar, syntax and mechanics. It is designed to facilitate the learning of sentence - level grammar and "no freedom to make mistakes" (Pincas, 1982, p.91). This approach focuses on accuracy rather than fluency: learners change words or clauses, combine sentences, fill in gaps or substitution; then, they are engaged in guided composition; after that they are allowed to engage in free autonomous writing. In this approach, the writer is simply a manipulator of previously learned language structure.

The Product Approach focuses on the final production of the piece of writing. It encourages analyzing students' product at the end of their writing, so that the teachers can recognize their learners' weaknesses. This approach focuses on accuracy, which can be achieved by imitating model texts. It involves the analyses and imitation of 
samples of reliable texts of various rhetorical patterns such as exposition, description, narration, classification, and argumentation. Students examine and study the model from all features: grammar, structure, content, organization, and rhetorical patterns; then they are given a writing task (new topic) which requires the reproduction of the textual acquired features. Finally, the produced texts are assessed by the teacher before going again through the same sequence using new literary text. This approach has been criticized because it gives little attention to the audience, the writers' purpose and their personal experience and moderates the learners' potential and affects their motivation and self esteem for example Kroll, 1991 and Harwood 2005 who blamed this approach for being mindless, repetitive and anti-intellectual.

The Process Approach comes as an alternative to the Product Approach in the mid 1970's (Kroll, 2001). Graham (1993) considered the Process Approach as a method that treats all kinds of writing and as a creative act which requires both time and positive feedback. Bachani (2010, p, 4) defined the Process Approach as a developmental approach which starts from generating ideas to expressing them: Pre-writing, drafting, revising, editing and publishing. The pre-writing is the crucial stage in the composing process. This stage is defined as thinking about the topic. It is a universal task that includes different strategies students use to gather, generate and explore ideas, information and details about the topic he decided on. These strategies are brainstorming, planning or outlining, listing, free writing, asking questions, visualizing, clustering, webbing and mapping. But the three first ones are the most commonly used. Drafting, the second stage of the writing process, involves the writers to get down their ideas and thoughts based upon the prewriting strategy that they have used. At this stage, the writers begin to "translate plans and ideas into provisional text" (Harris 1993, p. 55). They decide what to include and what to exclude from the information gathered as he arranged and organized them. Hedge (2005, p.54) explained that "the drafting process focuses primarily on what the writer wants to say, while redrafting progressively focus on how to say it most effectively". Revising, the third stage of the Process Approach is the most important stage where the writers evaluate, criticize and make improvement of their piece of writing. During this stage, the writers can add, omit, correct, order, change, reconstruct meaning, arrange and organize in 
order to clarify their message and improve their text with more effective vocabulary. Brown and Hood (1989) stated that the revising stage is very helpful and beneficial to writers. It is considered as a regular and the most important stage of the whole writing process. Gough, (2005, p. 16) said that "the more eyes that see and evaluate a piece of writing, the better it will appear". Sharing the same idea, Tompkins et. al., 2014 say that revising means "seeing again" and they advise writers to give more time and attention required to this very important stage. Editing, the next stage in the Process Approach, is reconsidering and checking the whole text to make sure that there are no errors which may obstruct communication. During this stage, experienced writers make use of checklists to keep focusing on perfecting their piece of writing. Publishing, the final stage of Process Approach, requires students to hand in their final products to their teachers for evaluation. Writers put their writing out to the public, the audience, to see its reaction: what readers think and how they feel while reading the piece of writing. Williams (2003, p. 107) defined publishing as "sharing your finished text with its intended audience, publishing is not limited to getting the text printed in a journal. It includes turning a paper in to a teacher, a boss, or an agency". These different stages of writing according to the Process Approach do not necessarily occur one after the other in a linear progression, they are recursive where the writer can move through these stages.

The Process Approach serves as a guide for students to help them develop an awareness of their own writing and provides them with opportunities to practise effective metacognitive strategies at each stage because good product depends on good process. This process "represent[s] the dominant approach in L2 writing teaching today" (Hyland, 2003, p. 14). Many educators were very positive towards the Process Approach since it is a learner-centered-approach that encourages students thinking and provides useful support and guidance to them while they write. For instance, Zamel (1983:147) held that "writing is a process through which students can explore their thoughts". He also believes that writing means thinking and students will benefit a lot from this cognitive process. According to Nemouchi (2008), the major aim of this approach is to train students how to generate ideas for writing, plan these ideas, take into account the type of audience,draft and redraft in order to produce a final written paper that is likely to communicate their ideas. 
All the previous approaches saw many critics.As a solution to these shortcomings, the Genre Approach appeared. Swales (1990: 22) defined a genre as "a class of communication events, the members of which share some set of communicative purposes". According to Hyland (2003),language is always occurring in particular social and cultural contexts, and thus, cannot be understood outside its context. The writer in this approach must produce texts that cope with the social context and designated to a specific audience. With the Genre Approach, the emphasis has moved from the composing process to the association between discourse and the context in which language is used. The main concern of this approach is then to teach students particular genres that they need to employ them in particular contexts. This might include a focus on the language and discourse features of the texts as well as the context in which the text is produced (Nemouchi, 2008, pp. 92-3). With the Genre Approach, writing is considered as a social and cultural activity which attempts to communicate with a specific audience in particular situations.

The Process Genre Approach has emerged to combine between the two complementary previous approaches: the Process Approach and the Genre Approach. The aim of this formed approach is to help students write following some stages and taking into consideration the purpose and the context. Badger \& White (2000) explained that this dual model allows learners to study the relationship between purpose and form for a specific genre while using the recursive process of the pre-writing, drafting, revision, and editing. This will evidently contribute to the development of students' creativity and the assimilation of the aspects of the target genres.

\section{Metacognition}

Learners differ in assimilating knowledge. There are those who are not aware of their thinking processes, who are not able to take charge of their own learning and who do not know what to do and how when facing learning tasks. There are others who possess a wide variety of thinking skills, who are aware of their knowledge, who know perfectly what to do and how when facing any learning situation. This second type of learners are said to have a conscious ability to recognize, understand, direct and control their knowledge. These learners are said to have a metacognitive awareness and use some metacognitive strategies. 


\subsection{Definition of Metacognition}

The term metacognition was first introduced by Flavell in the late 1970's. It is an important concept in cognitive theory. Metacognition refers to the reflective awareness of an individual's own cognitive processes and self-regulation. It is "an active, reflective process that is explicitly and exclusively directed at one's own cognitive activity. It involves the - monitoring, self-evaluating, and self-regulating of ongoing tasks" (Kluwe, 1982; cited in Berardi-Coletta et al.,1995 Students can control their goals, disposition and attention if they are aware of their knowledge. Psychologists suggest that if learners are able to gain insight into their own thoughts process and understand the ways in which they learn, they are expected to make good progress and achieve a successful learning. Metacognitive strategies are a procedure that one follows to control cognitive activities, as well as to ensure that a cognitive goal (set before) has been met. The same idea is shared by Taylor (1999), he defines metacognitive knowledge as "an appreciation of what one already knows, together with a correct apprehension of the learning task and what knowledge and skills it requires, combined with the ability to make correct inferences about how to apply one's strategic knowledge to a particular situation, and to do so efficiently and reliably". Metacognitive strategies are said to oversee learning and regulate learners' performance. They involve strategies for self-regulation, planning and monitoring cognitive activities, as well as checking the outcomes of those activities (Schunk, 2009).

\subsection{Types of Metacognitive Knowledge}

Various researchers distinguish three types of metacognitive knowledge: declarative, procedural, and conditional divisions. (Jacobs and Paris, 1987; Moshman, 1995; Schraw, 1998; Dantonio and Beisenherz, 2001). They emphasized the importance of these three types of knowledge because they facilitate the task for students to cope and to adapt to the changing situational demands. In order to increase their metacognitive abilities and to apply metacognitive strategies successfully, learners need to differentiate these three types of knowledge. Declarative knowledge is the factual information that one possesses. It requires individuals to be aware of their learning and the variety of factors that influence one's achievement. Examples of declarative knowledge are knowing the formula to calculate momentum (mass time velocity) in a physics class, calculating an equation in a math 
class or adding "ed" to regular verbs to form the past tense in grammar class. So, facts and rules are necessary to execute a task. Procedural knowledge"... is the mental steps, processes, or phases that represent how we arrive at information or details of how a cognitive operation is carried out" (Dantonio \& Beisenherz, 2001, p.44). It is knowledge of how to do and to carry a task and the different steps in process that one follows to perform that task. Procedural knowledge allows individuals to perform tasks more automatically, as they typically have more strategies and are able to apply such strategies more effectively. An example of procedural knowledge is showing how to skim, how to scan and how to summarize while reading. Conditional knowledge is the knowledge of strategies and skills and knowing how to use them, why certain strategies work, under what conditions and why one strategy is better than another. "It relays the conditions under which something is to be done or applied"(Dantonio \& Beisenherz, 2001, p44).

\subsection{Metacognition and the Writing Skill}

Metacognition is very important for successful learning. It is needed in every field of education. In writing for instance, students use metacognitive strategies. Emig (1977) said that writing constitutes a unique learning strategy linked to the development of thinking (i.e., a reasoning process). While writing a composition, students might go through a writing process. This process can be viewed as a cognitive activity. According to Flower and Hays (1981), the cognitive process of writing consists of three major components: planning, translating and reviewing which are under the control of a monitor. But other researchers extended the process to five steps. First, the pre-writing phase where learners gather information about their topic by using different strategies such as brain storming, clustering, visualizing, mapping, asking" wh" questions about the topic etc . Then, comes the second step where students write their plan about the topic. Once the plan is drawn, students start to write freely their first draft. Then, they move to the next step: the reviewing. In this step, students revise and correct their errors. When they finish revising, students go to the final step: editing, where they ask how well the goals have been met. During this process, students must know their objectives and how they plan on 
meeting them. The major objective of the writer is of course to meet the requirement of his audience which is indeed a very difficult task.

Brown, Campione and Day (1981) added further clarifications that the learner should consider personal characteristics such as limited short term memory, capacity and store of appropriate background knowledge on the topic. While writing, the learner should try to integrate text content with prior knowledge, i.e. to understand the new from what is already known. To have learners reflect on their writing practices, Harris and Graham (1985) concluded a study about teaching a group of twelve year old learners who had difficulty with writing composition some key aspects of composing a quality piece of writing. The group was engaged in thinking exercises, practising frequently, and obtaining regular feedback improved both the efficiency and the quality of the learners' writing. Some other researchers (such as White 1994) have chosen to investigate learners' metacognitive awareness by having them engaged in journal writing activities (learning log), a kind of diary of process in which learners reflect upon their thinking, make note of their awareness of difficulties and comments on how they have dealt with the writing task. Journal writing makes others gain insight into one's thinking, as it assures thinking with continual practice. Writing is then a mental learnt skill and a conscious practice that can lead students to become unconsciously metacognitive; they are always thinking, reflecting and even criticizing and evaluating their own work.

\section{Motivation}

Motivation is a crucial concept and an essential ingredient in learning. Without motivation, learning cannot take place and cannot be effective.

\subsection{Definition of Motivation}

Motivation is derived from the Latin word "movere" which means "to move", which implies a dynamic process because a movement is active. In order to achieve their goal, individuals move using their capacities and efforts. It is the inner drive that helps one meet and achieve their desired goals or rewards. Slavin (2006, p. 117) said that "Motivation is an internal process that activates, guides, and maintains behavior over time". Motivation is a whole procedure that stimulates and maintains behaviours to reach long-term goals. It is considered as a crucial element, a major key variable that influences success in learning in general and learning a foreign language in particular. Without motivation, learning cannot take place and even 
talented learners cannot complete long term goals. Being motivated is having a deep desire to achieve a well defined goal. It is a force that pushes the person to accomplish a given task. This force can be intrinsic or extrinsic. Intrinsic motivation is an action of appealing activity which is pleasant and agreeable to perform. Deci and Ryan, (1985, p.39) define intrinsic motivation as "motivation to engage in an activity because that activity is enjoyable to do", it is seen as voluntary and spontaneous and independent of reinforcement or Biological drives, and it needs no external reward. Extrinsic motivation, on the other hand, is an "action carried out to achieve some instrumental end such as earning a reward or avoiding a punishment" Deci and Ryan (1985, p. 39). According to this definition, people who are extrinsically motivated usually perform activities to reach some instrumental goals. It can be applied to activities that hold no interest or fun, for instance teacher encourages his learners to perform these tasks in return to some rewards and praises.

\subsection{Motivation and the Writing Skill}

Academic writing achievement is directly linked to motivation as most teachers of writing perceive that most students get bored whenever they are asked to write. Writing is not an enjoyable task for them. It is not absolutely a welcomed behaviour. While writing, inexperienced writers usually lose the ability to put words on paper or even struggle to generate information for the text. This blockage that prevents effective writing from taking place could be caused by many factors, but the lack or low motivation is considered as the chief obstacle. Motivational deficit is then the main problem in learning. When learners are not motivated to write, this will affect negatively their performance and hinders their writing development. Although teachers cannot make writing a pleasure for all their learners, they can motivate them to write and help them feel self confident and self efficacious. Increasing students' motivation for writing does not mean raising directly students' writing competence, but it helps students gradually generate knowledge, attention and more efforts to write. With high motivation and intensive training and practice, learners can improve their writing skill and become creative. Mac Groarty (1993) argued that learners with positive attitude, concrete goals and high motivation will certainly have these attitudes strengthened and achieve success in their writing experience. 
When involved in the process of writing, the first task students do is to activate their goal setting for writing (Poon, 2007). So, being motivated and having strong reasons for learning will help students to improve their skills and performance in writing.

4. The Study

In this research, we aim to motivate Second Year students of English at the Department of Letters and English, University "Frères Mentouri" Constantine 1 in order to help them improve their writing compositions. Our tenet and underlying aim is to show how metacognitive strategies and motivation interact to contribute to students' achievement and promote the development of writing skill and lessen the mistakes committed by learners and thus producing competent and successful writers.

\subsection{Population and Sample of the Study}

The sample involves sixty students (two groups of thirty students per group) chosen randomly from the population of second-years. A decision was taken to choose university students because at this level, learners are supposed to be active contributors in the learning process. They are expected to take responsibility for their own learning (Learner Centered Approach) and the teacher's role is to give information, to guide them, to control and give feedback to their production. From the two groups, one serves as an experimental group who receives the treatment whereas the other stands as control group and receives no treatment. They are both male and female students of about 20-23 years old. They share the same cultural background: they are from Constantine or Mila (Oued el Athmania, Telaghma, Chelghoum el Aid). The reason behind choosing Second Year students and not the others is that these students have already been exposed to a paragraph writing in their first year, and this year (second) the participants follow compulsory writing module for about 24 weeks; with three sessions per week (an hour and half for each session), dispersed into two semesters. During these sessions, the students follow a particular programme that allows them to write a whole essay.

\subsection{Research Questions and Hypotheses}

In this research, we propose to answer the following questions:

-Can metacognitive instructions help the students to improve their writing skill?

-Is there a connection between metacognition and motivation?

-How can teachers motivate their students to write? 
-What are the factors that create a motivational classroom atmosphere? In the light of the aforementioned research questions, the following hypotheses are formulated:

1. If students receive explicit metacognitive instructions as strategies to write essays, they will improve their writing skill.

2. If students use the Process Approach as metacognitive strategies while writing, they will develop a better performance.

3. If teachers manage to motivate their students and provide them with metacognitive instructions while writing, they will achieve a successful writing.

\subsection{Means of Research}

The research tools that are used to collect information in this work incorporate three complementary means. First, a questionnaire is administered to the teachers of Written Expression at the Department of Letters and English, University Constantine 1. It consists of 32 questions in order to gather information about the teachers' attitudes towards some problematic issues related to the current research and to know more about metacognition and motivation in Higher Education, mainly the department of Letters and English. We asked them about their experience with their students, how to motivate them, how to develop their metacognition and how to avoid a lifeless class. Second, another questionnaire (of 38 questions) is administered to Second Year students of the same department in order to gather information about the problems that they usually encounter while writing and to find out their perceptions about the use of metacognitive strategies as a motivating method to improve their written skill. In order to accomplish the experimental part of the study, a pre - post test is also used. The students were asked to write a five paragraphs essay about "Problems working mothers face in their everyday life". This topic is assigned by the teacher / the researcher. The selection of this topic is motivated by the fact that most students are women and they prefer such topics to express their ideas freely. It is used to gather data about the students' written production. The experimental group went through a treatment that lasted eight weeks, two sessions per week of fourty five minutes where the students received explicit instruction about how to write a good essay. The control group, on the other hand, did not receive any instruction during their writing skill practice. 


\subsection{Discussion of the Results of the Teachers and the Students Questionnaires}

The analysis of the teachers' responses yielded significant data in that they provide a general understanding of their attitudes, perspectives and difficulties in their writing classes. The main points are as follows.

- An important percentage of the teachers are dissatisfied about their students' level, which implies that they are aware of their students' weaknesses and they undoubtedly try to find ways and strategies to improve their students' level.

- All the teachers are conscious about the role of the strategies and agreed that the most successful learners are the strategic ones. Indeed, strategies can "pave the way toward greater proficiency, learner autonomy, andself-regulation"Hsiao and Oxford (2002, p. 372).

- The teachers urged the use of Metacognitive strategies because they enable students to benefit from instruction and sway the use and maintenance of cognitive strategies.

-While writing, it is better for the learners to follow Metacognitive instruction (i.e. the writing process) which provides them with both knowledge of cognitive processes and strategies that facilitate the task of writing.

- The teachers advise the use of metacognitive strategies because they help the students to become more strategic, self-reliant, flexible, and productive in their learning activities.

- Concerning motivation, most teachers are not satisfied with their students' level of motivation. They try hardly to stimulate their desire to write and create a good motivated and active class. So motivation is indispensable for achieving effective writing.

- Metacognition knowledge teaches the students to be more aware of their learning processes and products as well as how to regulate those processes for more effective learning in general and writing in particular.

- Strategic students should develop a kind of metacognitive regulation and control, and hence become self- evaluators of the outcomes of their efforts. So, Metacognition is a vital element in understanding successful performance. 
The Role of Metacognition and Motivation in Developing the

Writing Skill: the Case of Second Year Students of English at University "des Frères Mentouri”" Constantine 1

The analysis of the students' questionnaire displayed some valuable information regarding the participants' positions and attitudes about the writing skill, as it reveals that the students have indeed pitfalls in writing. Producing well-formed essays remains a daunting task for most students. The great majority of the students assert that they rely on the teacher to help them and provide them with strategies needed to develop their writing. They strongly believe that it is the role of the teacher to create the desire inside them and push them to practise writing and achieve a better performance.

As far as the use of the writing approaches is concerned, the results obtained determined that both the teachers and the students prefer the Process Approach better than the others. The writing process is a useful metacognitive strategy that helps the students to minimize the difficulties they encounter while writing. The Students will benefit a lot from this cognitive process: it not only facilitates the writing task, but also enables them to develop their performance and achieve a successful production.

4.5. The Experiment: The Pre-test, Instruction and the Post -test

Only the experimental group received a treatment which is explicit teaching instructions about metacognitive awareness through the use of the Process Approach from the beginning to the end, showing its steps, including visualizing what to write (by using mind maps or clusters...), planning the outline, drafting (sometimes redrafting when it is necessary), revising and rewriting the whole essay, then finishing it in an organized and appropriate form. The students of the experiment group were supposed to have sufficient input (prior knowledge) of the different steps of writing and aware enough about how to follow these steps. These students had also been familiar with the major elements to produce coherent and well organized essays.

After this treatment which lasted more than two weeks, three sections per week the participants of both groups went through: the posttest phase where they required to write the same topic as the pre-test, The main purpose of this post-test was to examine the experimental group's awareness about the importance of following the writing process stages, mainly planning, drafting, revising, and editing, and to check whether there is any difference between their performance before and after the treatment. We compared the performance of this group with the 
control group who did not receive any teaching treatment. Finally, the students' essays of the post-test were collected and corrected by the researcher using the Hyland 2003 Analytic Scoring Rubric to guarantee to a large extent reliable data and results.

\begin{tabular}{|c|l|}
\hline $\begin{array}{c}\text { Mark } \\
\text { excellent } \\
\text { To very good }\end{array}$ & $\begin{array}{l}\text { Organization and coherence 20 marks } \\
\text { thorough development through introduction, body, and } \\
\text { conclusion; relevant and convincing supporting } \\
\text { details; logical progression of content contributes to } \\
\text { fluency; unified paragraphs; effective use of } \\
\text { transitions and reference. }\end{array}$ \\
\hline $11-15$ & $\begin{array}{l}\text { Message mostly followed with ease; satisfactorily } \\
\text { organized and developed through introduction, body } \\
\text { and conclusion; relevant supporting details; mostly } \\
\text { logical progression of content; moderate to good } \\
\text { fluency; unified paragraphs; possible slight over- or } \\
\text { under-use of transitions but correctly used; mostly } \\
\text { correct references }\end{array}$ \\
\hline $\begin{array}{c}\text { 6-10 } \\
\text { fair to poor }\end{array}$ & $\begin{array}{l}\text { Message followed but with some difficulty; some } \\
\text { pattern of organization-an introduction, body, and } \\
\text { conclusion evident but poorly done; some supporting } \\
\text { details; progression of content inconsistent or } \\
\text { repetitious; lack of focus in some paragraphs; over- or } \\
\text { under-use of transitions with some incorrect use; } \\
\text { incorrect use of reference }\end{array}$ \\
\hline $1-5$ & $\begin{array}{l}\text { Message difficult to follow; little evidence of } \\
\text { organization-introduction and conclusion may be } \\
\text { missing; few or no supporting details; no obvious } \\
\text { progression of content; improper paragraphing; no or } \\
\text { incorrect use of transitions; lack of reference } \\
\text { contributes to comprehension difficulty }\end{array}$ \\
\hline inadequate
\end{tabular}

Table: 1. An Analytic Scoring Rubric (Hyland 2003, p. 243) 
The Role of Metacognition and Motivation in Developing the

Writing Skill: the Case of Second Year Students of English at University "des Frères Mentouri" Constantine 1

The results obtained by both the Control Group and the Experimental Group during the pre-test are grouped in Table 2.

\begin{tabular}{|c|c|c|}
\hline $\begin{array}{c}\text { Pre-test } \\
\text { Score/20 }\end{array}$ & $\begin{array}{c}\text { Control Group } \\
\text { Students/30 }\end{array}$ & $\begin{array}{c}\text { Experimental Group } \\
\text { Students/30 }\end{array}$ \\
\hline $\begin{array}{c}16-20 \\
\text { Excellent to very good }\end{array}$ & 00 & 00 \\
\hline $\begin{array}{c}11-15 \\
\text { Good to average }\end{array}$ & 12 & 11 \\
\hline $\begin{array}{c}6-10 \\
\text { Fair to poor }\end{array}$ & 17 & 18 \\
\hline $\begin{array}{c}1-5 \\
\text { Inadequate }\end{array}$ & 01 & 01 \\
\hline
\end{tabular}

Table 2. Comparison of the Results between the Control Group and the Experimental Group during the Pre-test.

Comparing the two groups, as shown in Table 2, the results obtained indicate that the two groups have approximately the same level. No student is noticed in the category of outstanding (from16-20), 12 students in the Control Group and 11 in the Experimental Group have scores between 11-15. These students manage to write satisfactory organized and coherent essays which contain introduction, body and conclusion with relevant supporting details; mostly logical progression of content; moderate to good fluency; unified paragraphs; possible slight over or under use of transitions but correctly used. In the category fair to poor (6-10), results revealed 17 students in the Control Group and 18 in the Experimental Group. The teacher/researcher found difficulty in correcting these compositions because they are poorly written: progression of content inconsistent, misuse of transitional markers, incorrect use of pronoun reference, useless repetitions. The results revealed that only 01 student in each group belongs to the category "inadequate (1-5)"; these students were unable to express their thoughts and organize their ideas in clear and comprehensible essays. They wrote a long paragraph, full of irrelevant sentences, lack of supporting details, lack of coherence. 
After the treatment, the two groups were asked to write an essay on the same topic. The results are as shown in Table 3.

\begin{tabular}{|c|c|c|}
\hline $\begin{array}{c}\text { Post-test } \\
\text { Score/20 }\end{array}$ & $\begin{array}{c}\text { Control Group } \\
\text { Students/30 }\end{array}$ & $\begin{array}{c}\text { Experimental Group } \\
\text { Students/30 }\end{array}$ \\
\hline $\begin{array}{c}\text { Excellent to very good } \\
11-15\end{array}$ & 00 & 03 \\
Good to average & 12 & 15 \\
\hline $\begin{array}{c}6-10 \\
\text { Fair to poor }\end{array}$ & 17 & 12 \\
\hline $\begin{array}{c}1-5 \\
\text { Inadequate }\end{array}$ & 01 & 00 \\
\hline
\end{tabular}

Table 3. Comparison of the Results between the Control Group and the Experimental Group during the Post-test.

Based on the findings of the students' performance in the pre -test and the post-test experimental study, there is a remarkable positive effect of the teacher's instructional treatment. The writing ability of the Experimental Group who had made use of meta-cognitive learning strategies surpasses that of the Control Group. While the results of the Control Group remain stable, the Experimental Group shows remarkable improvements. Three out of thirty of the participants are in the category of excellent and very good. Half of the students got from 11-15. 12 students got average marks not less than 08.5, and no one wrote an inadequate composition. The teacher/researcher is extremely satisfied with the experimental group result: most participants of this group followed all the stages of the writing Approach from brainstorming to publishing. The participants achieved a high standard of expressive writing. i.e., they wrote what they wanted to say with clarity and precision; they also minimized their errors and polished their final production. Thus, the teacher's instructions and encouragements for the students to monitor their own progress in writing enabled them to obtain better results in the post-test. Because the students know during the treatment that planning or outlining is a very important strategy going through the whole writing process, they began with establishing an outline to follow for the sake of assuring the form of the essay, unity and coherence in their productions. They also know that in the planning process, writers form an internal representation of the knowledge that 
will be used in their productions. However the control group started directly writing the essay, they think that drawing an outline is a waste of time. What is astonishing and even surprising is that the researcher noticed that students of the control group take much longer time to write the required parts of the essay than others in the experimental group. So, we can deduce that organizing and planning are metacognitive strategies used to facilitate the achievement of knowledge, and improve the performance of learners and the most achiever learners are the most strategic ones. Hence, our hypotheses (If students receive explicit metacognitive instructions as strategies to write essays, they will improve their writing skill, andif students use the process approach as metacognitive strategies while writing, they will develop a better performance) are strongly confirmed.

The participants achieved a high standard of expressive writing. i.e., they wrote what they wanted to say with clarity and precision. They also minimized the rate of their errors and polished their final production; this is probably due to the fact that these students revised and evaluated their compositions before they submitted them to their teacher. So, the participants of the experimental group while composing, they also monitor their current process and progress. Thus the teacher's instructions and encouragements for students to monitor their own progress in writing enabled to obtain better results in the post-test. Whereas many students of the control group, unfortunately, are still unable to express themselves in a clear, correct and comprehensible manner in writing. We can deduce that the use of metacognitive strategies can be associated with successful learning since only the experimental group who received the training shows the best and the brightest outcome. So, Metacognitive strategies must be taught to all students.

Implementing metacognitive tasks means transferring some responsibilities to learners, which, in turn, might increase their efforts, it is therefore suggested that explicit and direct instruction and guided practice be consistently provided. When teaching writing metacognitively, the teacher becomes supportive to his/her learners, and respects their opinions. The teacher should also push the learners to monitor, self evaluate and self regulate their efforts as well as their 
writing productions. Thus, the learners become autonomous and responsible for their own learning (learner-centered approach).

\section{Conclusion}

The writing skill intersects with the requirements of not only metacognitive strategies but also of a motivation and a desire to write and to improve this skill. To create a good and healthy classroom, both teacher and learners should contribute: learners should come to the course with a goal set and with high motivation. The teacher's task is primary to establish suitable learning conditions in the classroom; and then behave in a manner that attracts and motivates his learners and favourites writing. The teacher should also provide his students with metacognitive instructional strategies to facilitate the writing task.

\section{References}

Angelillo, J. (2002). A Fresh Approach to Teaching Punctuation. New York: Scholastic, Inc.

Bachani, N. (2010). Teaching Writing.Oxford University Press

Badger, R., and White, G. (2000). Product, Process and Genre: Approaches to writing in

EAP [Electronic version]. Oxford University Press: ELT Journal, 54(2), 153-160

Berardi-Coletta, B., et al., (1995). Metacognition problem solving: A process-oriented

approach. Journal of Experimental Psychology: Learning, Memory, and

Cognition, 21(1), 205-223.

Brown, A.L. Campione, J.C. and Day, J.D. (1981). Learning to Learn: On Training

Students to Learn from Texts. Educational Researcher V10 (2).pp.14-21.

Brown, J.D. (1988). Research in second language learning. Cambridge

: Cambridge

University Press

Canale, M., and Swain, M. (1980). Theoretical bases of communicative approaches to

second language teaching and testing.Applied Linguistics, $1(1), 1-47$. 
The Role of Metacognition and Motivation in Developing the

Writing Skill: the Case of Second Year Students of English at University "des Frères Mentouri”" Constantine 1

Canale-Swain.pdf

from:http://ibatefl.com/wpcontent/uploads/2012/08/CLT-

Carroll, R.T. (1990). Students success guide: Writing Skills.

www.skepdic.com/refuge/studyskills1.pdf

Emig, J (1977). "Writing as a Mode of Learning." College Composition and Communication

Communication 28 (1977): 122-28

Flower, L. and J. Hayes. (1981). A cognitive process theory of writing. College

Composition and Communication , (pp.365-87)

Grabe, W. and Kaplan, R. B. (1996). Theory and Practice of Writing.

London and New York: Longman.

Harris, K. R., \& Graham, S. (1985).Improving learning disabled

students' composition

skills: Self-control strategy training. Learning Disability

Quarterly, 8, 27-36.

Hedge, T. 2005. Writing. Oxford University Press.

Hyland, K. (2003). Second Language Writing. Cambridge: Cambridge University Press.

Jacobs, J., \& Paris, S. (1987). Children's metacognition about reading. Issues in definition, 255-278.

measurement, and instruction. Educational Psychologist, 22,

Kroll, B. (1997). Second Language Writing: Research Insights for the

Classroom.

Cambridge: CUP

Kroll, J. F (2001). The Development of Lexical Fluency in Second Language.

Mc Carthey, M.(1991).Discourse Analysis for Language Teachers.

Cambridge: Cambridge

University Press.

Murray,N. and Hugles, G. (2008). Writing up your university assignments and research projects: A practical handbook. Open University, McGraw-Hill Education:Maidenhead.

Nemouchi, A. (2008). Writing Connection with Grammar and Literature in the Study

Organization of the LMD System, University of Constantine. 
Oxford, R. (1990). Language learning strategies: What every teacher should know.

Rowley, M.A.: Newbury House.

Pincas, A, .1982 .Writing in English. Book 1. London Macmillan.

Raimes, A. (1983). Techniques in Teaching Writing. Oxford University Press

Scarry, S. and J. Scarry. (2014). The Writes Workplace with Readings (8th ed.). Boston:

Wadsworth Cengage Learning.

Silva, T. (1990). Second language composition instruction: Developments, issues, and directions in ESL. In B. Kroll (Ed.), Second language writing: Research Insights for the classroom (pp. 11-23). Cambridge, UK: Cambridge University Press.

Schunk, D. H. (2009). Learning theories: An educational perspective. Pearson Prentice Hall: North Carolina University.

Starkey, K. (2004), Rethinking the Business School.V41 (8).Journal of Management Studies.

Swales, J. M. (1990). Genre Analysis. Cambridge: Cambridge University Press.

Swales,J.M. and Feak, C. (2004). Academic Writing for Graduate Students. Essential Tasks and Skills. Cambridge Applied Linguistics

Taylor, G. (1999). The organization of information.Cambridge: Cambridge University Press.

Tribble, C. (1996). Writing Oxford: Oxford University Press.

White, R. and Arndt, V.1991. Process Writing. London and New York: Longman.

White, E. M. (1994). Teaching and assessing writing: recent advances in understanding, evaluating, and improving student performance. San Francisco: Jossey-Bass Publishers.

Zamel, V. (1983). The composing processes of advanced ESL students: six case studies. TESOL Quarterly, 17, 165-187. 